\title{
Understory species response to Utah juniper litter
}

\author{
CHAD S. HORMAN AND VAL JO ANDERSON
}

Research Associate and Professor, Botany and Range Science Department, Brigham Young University, Provo, Ut. 84602.

\begin{abstract}
A greenhouse study was conducted to determine the effects of litter leachate and litter depth of Utah juniper [Juniperus osteosperma (Torr.) Little] on seedling emergence and emergence rate of 8 common herbaceous understory species. Species tested were: 'Secar' bluebunch wheatgrass [Pseudoroegnaria spicata (Pursh) A. Love], bottlebrush squirreltail [Elymus elymoides (Raf.) Swezey], cheatgrass (Bromus tectorum L.), 'Paiute' orchardgrass (Dactylis glomerata L.), 'Appar' Lewis flax (Linum lewisii Pursh), 'Delar' small burnet (Sanguisorba minor Scop.), antelope bitterbrush [Purhsia tridentata (Pursh) DC.], and mountain big sagebrush [Artemisia tridentata spp. vaseyana (Rydb.) J. Boivin]. Three water treatments (distilled water, $1 \%$, and $10 \%$ litter leachates) and 3 litter depths $(0,3$, and $5 \mathrm{~cm})$ were tested. Leachates decreased seedling emergence of orchardgrass and small burnet. Emergence rate was unaffected by leachate treatments. Seedling emergence of all species tested decreased significantly with increasing litter depth. Emergence rate was initially slower in pots with litter, but after 2 weeks no differences were found.
\end{abstract}

Key Words: leachate, litter depth, allelopathy, plant competition, Juniperus osteosperma, emergence

The pinyon (Pinus spp.)-juniper (Juniperus spp.) woodland is an important ecosystem of the western United States, comprising about 25 million hectares throughout Nevada, Utah, Colorado, New Mexico, and Arizona (Hurst 1987). In pre-settlement days, juniper was most abundant in the southwestern U.S., but distinct populations could be found on rocky mid-elevation foothills of the Great Basin (Welch et al. 1987). Since the mid-1800's, juniper has slowly encroached into the valleys of the Great Basin. As juniper becomes the dominant species in these communities, elements of both the biotic and abiotic environments have been modified (Tausch et al. 1981). This has created a serious problem for land managers, because as these trees come to dominate a site, the herbaceous understory is severely reduced (Tausch and Tueller 1977). Increased runoff and soil erosion have been reported as a result of the plant community shift (Farmer 1995). Hypotheses to explain how junipers are able to dominate a site include: 1) increased canopy cover which creates shading (Schott and Pieper 1985) and intercepts precipitation (Skau 1964, Gifford 1970), 2) deep litter accumulation (Jameson 1966) 3) allelopathy (Lavin et al. 1968, Peterson 1972), 4) changes in the soil nutrient composition (Doescher et al. 1987, Tiedemann 1987), and 5) competition for soil moisture (Miller et al. 1987, Breshears et al. 1997)

Litter affects the understory either due to its depth (Everett and Koniak 1981) or to allelopathy (Lavin et al. 1968, Jameson 1970). In a mature stand of one-seed juniper [Juniperus monosperma (Engelm.) Sarg.], Jameson (1966) stated that litter

\section{Resumen}

Se condujo un estudio de invernadero para determinar los efectos del lixiviado del mantillo y la profundidad del matillo de "Utah juniper" [Juniperus osteosperma (Torr.) Little] en la emergencia de plántulas y la tasa de emergencia de 8 especies herbáceas comunes. Las especies evaluadas fueron: 'Secar' "Bluebunch wheatgrass" [Pseudoroegnaria spicata (Pursh) A. Love], "Bottlebrush squirreltail" [Elymus elymoides (Raf.) Swezey], "Cheatgrass" (Bromus tectorum L.), 'Paiute' "Orchardgrass" (Dactylis glomerata L.), "Appar' "Lewis flax" (Linum lewisii Pursh), 'Delar' "Small burnet" (Sanguisorba minor Scop.), "Antelope bitterbrush" [Purhsia tridentata (Pursh) DC.] y "Mountain big sagebrush" [Artemisia tridentata spp. vaseyana (Rydb.) J. Boivin]. Se probaron tres tratamientos de agua (agua destilada y lixiviados del mantillo al $1 \%$ y $10 \%$ ) y tres profundidades de mantillo $(0,3$ y $5 \mathrm{~cm})$. Los lixiviados disminuyeron la emergencia de plántulas del "Orchardgrass" y "Small burnet". La tasa de emergencia no fue afectada por los tratamientos de lixiviado. La emergencia de plántulas de todas las especies disminuyo significativamente al incrementar la profundidad del mantillo. La tasa de emergencia inicialmente fue lenta en macetas con mantillo, pero después de dos semanas no se encontró diferencia.

accumulation was more detrimental than shading. He found blue grama [Bouteloua gracilis (Willd. ex Kunth) Lag. ex Griffiths] basal area and production were not affected by the roughly $40 \%$ shading, but litter accumulation did adversely affect them both. Johnsen (1962) demonstrated that a significant reduction occurred in blue grama emergence with as little as $2.5 \mathrm{~cm}$ of litter.

It has been reported that juniper litter may be allelopathic (Lavin et al. 1968, Peterson 1972). Allelopathy is defined “....as any direct or indirect harmful effect of one plant on another through production of chemical compounds that escape into the environment" (Rice 1984). With respect to allelopathy in juniper species, the literature contains conflicting evidence as to whether or not it really occurs. Jameson (1970) identified 2 compounds from Utah juniper that were considered possible growth inhibitors. Peterson (1972) found that Rocky Mountain juniper (Juniperus scopulorum Sarg.) produced both water soluble and volatile inhibitors that reduced germination of several herbaceous species. Lavin et al. (1968) reported that allelopathy in Utah juniper was species specific. Johnsen (1962) found that one seed juniper extracts did not significantly reduce blue grama germination.

This study was conducted to better understand the effects Utah juniper litter depth and allelopathy have on seedling emergence and emergence rate of 8 potential understory plant species of central Utah. 


\section{Materials and Methods}

This study tested the effects of 3 water treatments [distilled water (control), $1 \%$ and $10 \%$ leachate concentrations made from Utah juniper litter] and 3 litter depths $(0,3$ and $5 \mathrm{~cm})$ on seedling emergence and emergence rate on the following species: 'Secar' bluebunch wheatgrass [Pseudoroegnaria spicata (Pursh) A. Love], bottlebrush squirreltail [Elymus elymoides (Raf.) Swezey], cheatgrass (Bromus tectorum L.), 'Paiute' orchardgrass (Dactylis glomerata L.), 'Appar' Lewis flax (Linum lewisii Pursh), 'Delar' small burnet (Sanguisorba minor Scop.), antelope bitterbrush [Purhsia tridentata (Pursh) DC.], and mountain big sagebrush [Artemisia tridentata var. vaseyana (Rydb.) J. Boivin].

Seed for all of the species, except mountain big sagebrush and cheatgrass, were purchased from a local seed dealer. Mountain big sagebrush seed was obtained from the USDA Forest Service Shrub Research Lab in Provo, Ut. Cheatgrass seed was collected in the summer preceding the study in Spanish Fork Canyon, Utah Co., Ut. Seeds were visibly inspected and used in the study if they had adequate seed fill and lacked any evidence of predation or parasitism. Seed viability, based on germination trials, ranged from $56 \%$ for orchardgrass to $99 \%$ for mountain big sagebrush, with most species in the 80-90\% range.

Allelopathic potential is usually tested using leachates made from plant material (Jameson 1970, Jobidon 1986). Leachate used in this experiment was made from juniper litter collected beneath Utah juniper trees in Spanish Fork Canyon. Litter was sifted through \#20 hardware mesh to separate soil from litter. A $1 \%$ leachate solution was prepared by soaking $1 \mathrm{~g}$ of litter in $100 \mathrm{ml}$ of distilled water for 24 hours at $20^{\circ} \mathrm{C}$. The leachate was then filtered through a \#60 mesh filter. A $10 \%$ leachate was made in the same fashion except that $10 \mathrm{~g}$ of litter per $100 \mathrm{ml}$ of water was used (Jobidon 1986).

Twenty centimeter diameter pots were filled with a soil mixture of 1 part sand and 1 part standard potting soil (Sunshine Mix \#3). Litter treatments of 3 depths ( 0 , 3 , and $5 \mathrm{~cm}$ ) were applied using litter collected beneath Utah juniper trees in Spanish Fork Canyon. The litter was placed in the pots on the soil surface at depths representative of the those found in the interspace $(0 \mathrm{~cm})$, the mid-canopy area $(3 \mathrm{~cm})$, and near the trunk $(5 \mathrm{~cm})$, respectively. Each pot was seeded with 1 of the 8

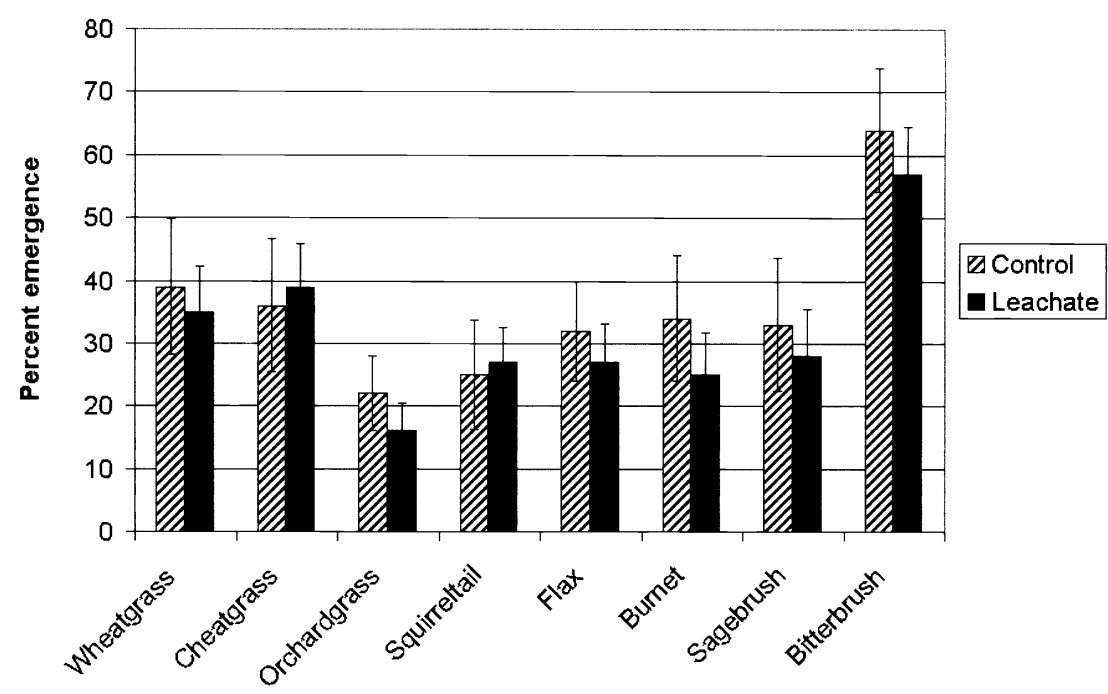

Species

Fig. 1. Response of understory species to imposed Utah juniper litter leachate.

species, with 50 seeds per pot. The seeds were broadcast on top of the surface material, either soil or litter, and then covered by lightly raking them into the surface material. Antelope bitterbrush was planted in 10 caches of 5 seeds at a depth of 2.5 to $3 \mathrm{~cm}$ beneath the surface material. This was done to simulate rodent caching, a common form of antelope bitterbrush seed dispersal (Vander Wall 1994). The pots were then watered until the soil was saturated with the respective water treatments (distilled water, $1 \%$ or $10 \%$ leachate) and placed outside in a lath house for 6 weeks (late December 1996 to early February 1997), to simulate a short wintering period. To prevent precipitation diluting the leachate, pots were placed beneath benches whose tops were covered with clear plastic. No additional watering occurred during this time, since soils were frozen. In February 1997, the pots were moved into a greenhouse with a 12 hour diurnal $20^{\circ} / 15^{\circ} \mathrm{C}$ temperature regime. Supplemental lighting was provided in order to increase existing photoperiod to springtime conditions of approximately 12 hours, using 400 watt sodium vapor lamps. Inside the greenhouse, the pots were watered to saturation with their assigned water treatment once a week. The experiment was a 2 factor complete factorial design with 3 litter depths $(0,3$, and 5 $\mathrm{cm})$ and 3 leachate concentrations [distilled water (control), $1 \%$, and $10 \%$ leachates] replicated 4 times in a randomized block design. Seedling density was counted daily for the first 3 weeks and then every 3 days for the remaining 5 weeks of the study.

An ANOVA analysis was performed, by species, using SAS (SAS 1999) statistical package and a Fisher's protected LSD was used for mean separation (Ott 1993). Differences were deemed significant at $\mathrm{P}$ $<0.05$ unless otherwise noted.

\section{Results \& Discussion}

The results of the 2 leachate treatments were not significantly different and were pooled for presentation. No significant interactions occurred, thus only the main effects (litter and water treatments) are presented here.

Of the 8 herbaceous understory species tested, only small burnet and Lewis flax showed any response to the leachate treatments (Fig. 1). Seedling emergence of small burnet and Orchard grass were reduced by $25 \%$ and $23 \%$ compared to the control treatment, respectively.

Emergence rate was defined as the total number of emerged seedlings per week. The leachate treatments had no significant effect on emergence rate (data not shown).

These results indicate that allelopathic effects of Utah juniper are species specific. Similar findings were reported for Rocky Mountain juniper by Peterson (1972) and for 1-seed juniper by Lavin et al. (1968).

The differences in the results of this study as compared to those indicating that juniper is allelopathic, may be due to methodology. The majority of allelopathy studies (Jameson 1961, Lavin et al. 1968, Peterson 1972) have tested leachates made from fresh foliage. It is possible that the negative effects observed in those studies 


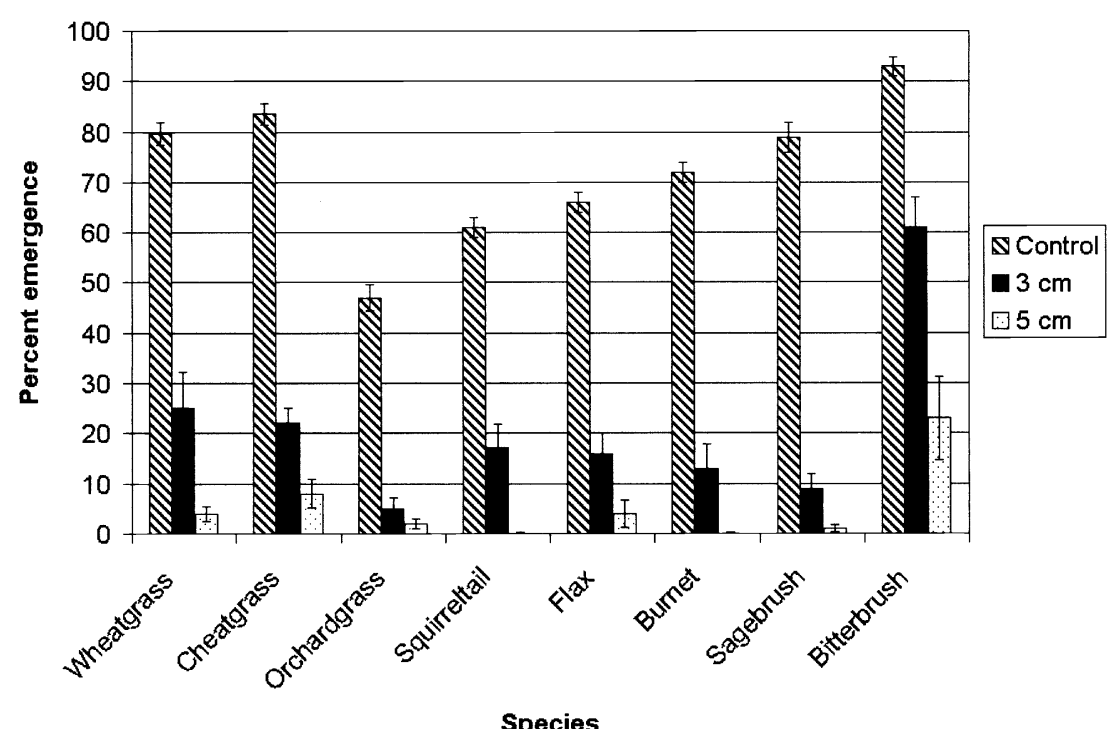

Fig. 2. Response of understory species to imposed Utah juniper litter depth.

may have been due to compounds that may be allelopathic, but are quickly degraded and lost once the foliage begins to decompose. Jameson (1966) identified 2 potentially allelopathic compounds in Utah juniper foliage and litter that behaved in just such a manner. The first compound, although allelopathic, degraded quickly enough that it never reached toxic concentration. The second compound had a slower decomposition rate and could accumulate if the right conditions occurred. This same thing may apply to other compounds in Utah juniper litter. When extracts from fresh foliage are used,

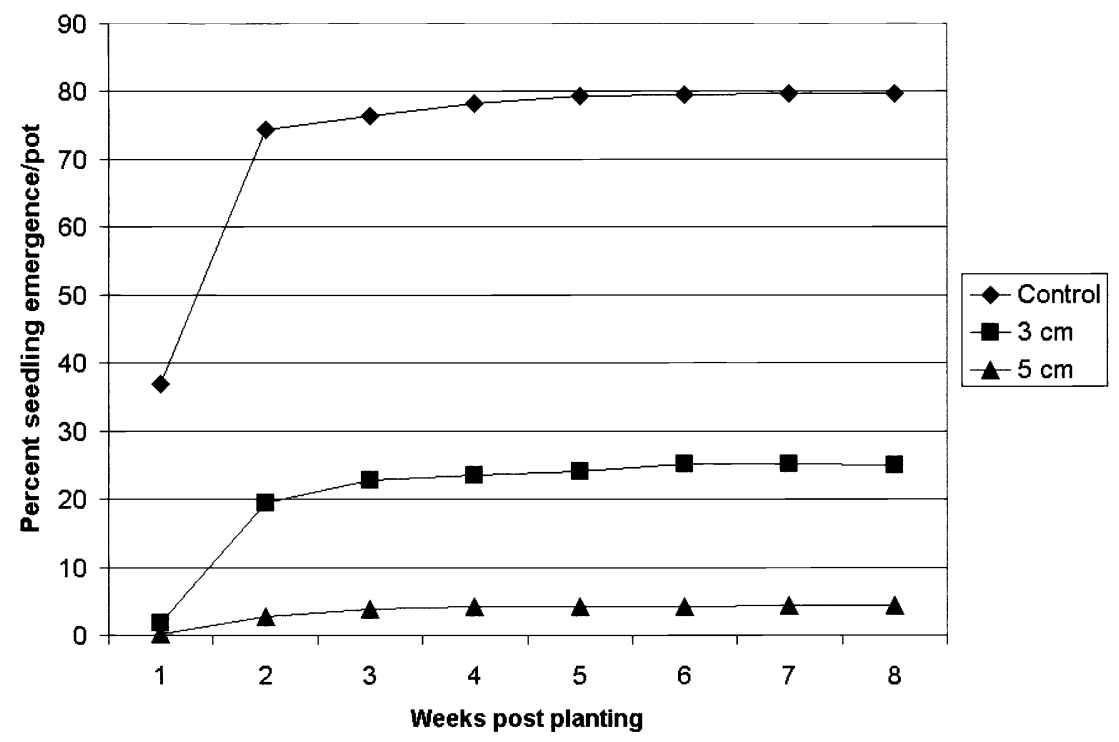

Fig. 3. Response of bluebunch wheatgrass emergence rate to increasing depth of Utah juniper litter. compared to control pots. A $90-100 \%$ decrease in emergence occurred in pots with $5 \mathrm{~cm}$ of litter compared to pots with no litter, except for antelope bitterbrush. Though not as severe as the other species, emergence of antelope bitterbrush was still strongly impacted by litter depth with a $34 \%$ and $75 \%$ decrease in emergence in pots with $3 \mathrm{~cm}$ and $5 \mathrm{~cm}$ of litter, respectively, compared to pots with no litter.

Emergence rate was also affected by litter depth. The response of bluebunch wheatgrass, shown in Figure 3, was typical of all species tested. During the first week of the study, seedling emergence was faster in pots with no litter than in pots with 3 or $5 \mathrm{~cm}$ of litter. However, by the end of the second or third week very little subsequent emergence occurred in any of the 3 litter treatments.

These findings support those of other researchers both in the laboratory and field. Johnsen (1962) reported that blue grama emergence was significantly reduced by as little as $2.5 \mathrm{~cm}$ of one-seed juniper litter. Jameson (1966) likewise reported that litter depth, not canopy shading, was responsible for low blue grama basal area and production in pinyonjuniper stands of Arizona. Schott and Pieper (1985) found that litter depth was negatively correlated with grass basal cover around one-seed juniper trees in New Mexico.

There are 2 possible reasons why litter depth reduces emergence. First, the litter may drain and dry out quickly which would limit moisture for imbibition. This would especially be the case if the seeds were at or near the litter surface as they were in this study, representing natural dispersal. The antelope bitterbrush results appear to support this hypothesis. The seeds were planted 2.5 to $3 \mathrm{~cm}$ below the surface material. In pots with $3 \mathrm{~cm}$ of litter, seeds were deposited at the soil-litter interface. While seeds in pots with $5 \mathrm{~cm}$ of litter were planted at the same depth, they still had about $2 \mathrm{~cm}$ of litter beneath them. The fact that emergence in the pots with 3 $\mathrm{cm}$ of litter was relatively higher compared to the other species was probably due to the seeds having adequate imbibition because of contact with the soil and the litter acting as a protective mulch. Whereas, antelope bitterbrush seeds in the pots with $5 \mathrm{~cm}$ of litter did poorly because they were in a much drier environment due to their placement in the middle of the litter profile.

This explanation may be influenced by the intensity and duration of a precipitation event. In the greenhouse the pots were 
watered with a watering can which dispensed the water rather quickly, much like a high intensity, short duration thunder storm. In this type of storm the litter would probably drain and dry rather quickly creating the aforementioned conditions. If, however, the storm was of a low intensity and long duration then the litter would stay moist longer which would allow for more imbibition to occur and subsequent higher germination.

The second possible explanation for the effect of litter depth is that the litter may simply be too deep creating an establishment barrier. It is possible that the emerging radicle may never be able to reach mineral soil in order to obtain water and nutrients. In trying to reach mineral soil the seedling uses up all of its energy stores and dies. The depth and physical structure of the litter may be a critical factor in determining seedling success for extremely small seeded species, such as sagebrush, that have limited energy reserves for radical growth. If the seedling radicle can reach mineral soil, then the litter ceases to be a barrier.

\section{Conclusion}

In summary, this study showed that Utah juniper litter leachates had a limited allelopathic effect on emergence of orchardgrass and small burnet under greenhouse conditions, supporting previous research that any allelopathic effects are species specific.

Litter depth was shown to drastically affect emergence and emergence rate. All of the understory species used in the investigation had a reduction in emergence as litter depth increased. Emergence rates of all 8 species were initially lower. However, by the end of the second week this effect was not noticeable. These findings indicated that litter beneath Utah juniper trees has a much stronger affect on plant emergence than does allelopathy.

\section{Literature Cited}

Breshears, D.D., O.B. Myers, S.R. Johnson, C.W. Meyer, and S.N. Martens. 1997. Differential use of spatially heterogeneous soil moisture by two semiarid woody species: Pinus edulis and Juniperus monosperma. J. Ecol. 85:289-299.

Doescher, P.S., L.E. Eddleman, and M.R. Vaitkus. 1987. Evaluation of soil nutrients, $\mathrm{pH}$, and organic matter in rangelands dominated by western juniper. Northwest Sci. 61:97-102.
Everett, R.L. and S. Koniak. 1981. Understory vegetation in fully stocked pinyon-juniper stands. Great Basin Natur. 41:467-475.

Farmer, M.E. 1995. The effect of anchor chaining pinyon-juniper woodland on watershed values and big game animals in central Utah. M.S. Thesis. Brigham Young Univ., Provo, Ut.

Gifford, G.F. 1970. Some water movement patterns over and through pinyon-juniper litter. J. Range Manage. 23:365-366.

Hurst, W.D. 1987. Management strategies within the pinyon-juniper ecosystem., pp. 187-194. In: Everett, R.L. (ed.), Proc. Pinyon-juniper conference. Gen. Tech. Rep. INT-215. USDA Forest Service Inter-mountain Res. Sta. Ogden, Ut.

Jameson, D.A. 1961. Growth inhibitors in native plants of northern Arizona. USDA Forest Service Rocky Mountain Forest and Range Exp. Sta. Res. Note No. 61. Fort Collins, Colo.

Jameson, D.A. 1966. Pinyon-juniper litter reduces growth of blue grama. J. Range Manage. 19:214-217.

Jameson, D.A. 1970. Degradation and accumulation of inhibitory substances from Juniperus osteosperma (Torr.) Little. Plant and Soil. 33:213-224.

Jobidon, R. 1986. Allelopathic potential of coniferous species to old-field weeds in eastern Quebec. Forest Sci. 32:113-118.

Johnsen, T.N., Jr. 1962. One-seed juniper invasion of northern Arizona grasslands. Ecol. Monogr. 32:187-207.

Lavin, F., D.A. Jameson, and F.B. Gomm. 1968. Juniper extract and deficient aeration effects on germination of six range species. $\mathbf{J}$. Range Manage. 21:262-263.

Miller, R.F., R.F. Angell, and L.E. Eddleman. 1987. Water use by western juniper, pp. 418-422. In: Everett, R.L. (ed.), Proc. Pinyon-juniper conference. Gen. Tech. Rep. INT-215. USDA Forest Service Intermountain Res. Sta. Ogden, Ut.

Ott, R.L. 1993. An introduction to statistical methods and data analysis. Wadsworth Publishing Co., Belmont, Calif. pp. 813-814.

Peterson, G.B. 1972. Determination of the presence, location and allelopathic effects of substances produced by Juniperus scopulorum Sarg. Diss. Abstr. B. 32:3811-3812.

Rice, E. L. 1984. Allelopathy. Academic Press, Inc. Orlando, Fla. pp 1

SAS. 1999. SAS user's guide: version 8. SAS Inst. Inc., Cary, N.C.

Schott, M.R. and R.D. Pieper. 1985. Influence of canopy characteristics of oneseed juniper on understory grasses. J. Range Manage. 38:328-331.

Skau, C.M. 1964. Interception, throughfall, and stemflow in Utah and alligator juniper cover types in northern Arizona. Forest Sci. 10:283-287.

Tausch, R.J. and P.T. Tueller. 1977. Plant succession following chaining of pinyonjuniper woodlands in eastern Nevada. J. Range Manage. 30:44-49.
Tausch, R.J., N.E. West, and A.A. Nabi. 1981. Tree age and dominance patterns in Great Basin pinyon-juniper woodlands. J. Range Manage. 34:259-264.

Tiedemann, A.R. 1987. Nutrient accumulations in pinyon-juniper ecosystems--managing for future site productivity, pp. 352-359. In: Everett, R.L. (ed.), Proc. Pinyon-juniper conference. Gen. Tech. Rep. INT-215. USDA Forest Service Intermountain Res. Sta. Ogden, Ut.

Vander Wall, S.B. 1994. Seed fate pathways of antelope bitterbrush: dispersal by seedcaching yellow pine chipmunks. Ecol.. 75:1911-1926.

Welch, S.L., N.D. Atwood, S. Goodrich, and L.C. Higgins. 1987. A Utah flora. Great Basin Natur. Memoirs. 9:27. 